\title{
pÿThe Grand Duchy of Finland and other prison in the Russian Empire
}

\section{Kangaspuro ( Orfinskaya), Larisa}

2021

pÿKangaspuro ( Orfinskaya) , L 2021 , ' The Grand Duchy of Finland and other prison in the pÿRussian Empire ' , 5B5@1C@3A:89 8AB>@8G5A:89 6C@=0; , no. 1/2021, pp. 76-82 .

http://hdl.handle.net/10138/332189

unspecified

publishedVersion

Downloaded from Helda, University of Helsinki institutional repository.

This is an electronic reprint of the original article.

This reprint may differ from the original in pagination and typographic detail.

Please cite the original version. 


\section{Larisa Kangaspuro}

\section{The Grand Duchy of Finland and "other" prison in the Russian Empire}

The Finnish penal system elicits interest the world over, and has served as a model for many countries. In particular, Finland is well known for its low incarceration rate, its wide-ranging use of rehabilitation programmes, and its system of open prisons. This paper discusses some background factors behind Finland's "success story".

The guiding premise of this study is that prisons reflect the societies, and societal changes, which surround them. According to Michel Foucault, prisons contain all the $\widehat{\widehat{I}}$ same mechanisms, which are already present in society. David Garland, a leading scholar in criminology and the sociology of law, strongly believes that by analysing crime control and available modes of punishment within a specific society, broader generalisations about social order and ways of governance within that society can be inferred ${ }^{1}$.

In the modern penal system, significant attention is paid to the rehabilitation of prisoners, with a view to their reintegration into society upon release. And this is far from being merely a $21^{\text {st }}$ century concern. The Progressive (or Irish) prison system, introduced in Ireland in 1854, aimed to return offenders to the community, transforming them from outsiders into fully-functioning citizens.

In this paper, I will explore the historical basis for social engagement of prisoners in the Finnish penal system. I will discuss how the model was developed in the $19^{\text {th }}$ century. What was the Finnish understanding of punishment and its aims? What place in the penal system was accorded to the rehabilitation of a criminal? Did Russian official and public debates influence the development of Finnish criminal justice? My paper will focus particularly on the question, how did the unique conditions of Finnish history affect the process of criminal rehabilitation? 
I will try to answer these questions by analysing archival materials from the period of Finnish autonomy, published legislative documents, journalism, as well as some researches on the issue. During that work, I found that there are in the National Archives of Finland abundant number of Russian language sources, which has not been used by other researchers.

The major study "Scandinavian Penal History, Culture and Prison Practice: Embraced by the Welfare State?"2, edited by Peter Scharff Smith and Thomas Ugelvik, and published a few years ago, looks conceptually attractive. Unfortunately, the scope of the study is limited geographically to the Scandinavian peninsula and though the editors mention the Finnish situation as a point of interest - does not include Finland. Finland, after all, occupies a particular status among the Nordic countries, because for more than one hundred years it was under the control of a non-Nordic country.

However, according to John Pratt ${ }^{3}$, a prominent researcher on the history and sociology of punishment, the Finnish prison system is a key component of Scandinavian Penal Exceptionalism, characterised by its humane attitude towards prisoners and protection of their rights. However, this was not always the way in Finland. It will suffice here to turn to historical narrative.

We all know that in 1809, Finland became a part of Russia while still preserving its Swedish laws. The aftermath of the Russian-Swedish war and the Finns' indefinite position led to an increase in crime. As was the case throughout Europe at the time, Finnish prisons were overcrowded and in unsatisfactory condition. In response to general unease amongst the population, the Finnish clergy proposed to exile "thieves" to Siberia ${ }^{4}$. The hope was that criminals, finding themselves unable to return to Finland, would forget the past, and begin a new life in Siberia. However this Finnish initiative was made law only after the ascension to the Russian throne of Nicholas I. Beginning in 1826, male prisoners who had been condemned to death by Finnish law and subsequently pardoned had their sentences commuted to hard labour (penal servitude) in Siberia ${ }^{5}$. In time, the category of Finns sent to Siberia was expanded. From 1848, convicted vagrants as well as women were sentenced to Siberian exile ${ }^{6}$. And only in 1888 (the year Finnish prison reform was completed) the deportation of Finns to Siberia was replaced by indefinite forced labour in domestic prisons. From that time, Finland began to take care of its own criminals. Finnish researcher Alpo Juntunen ${ }^{7}$ provides a detailed discussion of this issue in his dissertation.

In the first decades of the $19^{\text {th }}$ century, industrialisation had not yet fully taken hold in Finland. Although the Grand Duchy's manufacturing power was, by all qualitative measures, superior to Russian analogues, Finnish national self-awareness was not yet born. Most importantly, the Grand Duchy lacked a national school of criminal law, capable of developing new concepts of crime and punishment. This would be essential if Finland was to create a fundamentally new criminal justice system. The situation changed only as a result of the rapid growth of industrialisation in 
the mid- $19^{\text {th }}$ century, along with the formation of a national market, the growth of self-awareness, culture (including legal culture), and the reinvigoration of the Diet of Finland.

Following the general European tendency, Finland too saw increased societal and government interest in prison reform from the mid-19 ${ }^{\text {th }}$ century onwards. Attentively studying foreign models, Finnish experts saw even then that the main goal of criminal justice must be the rehabilitation and social reintegration of the offender. The resolution passed by the Finnish Senate in $1866^{\circ}$, which took action in 1870, signalled the transition from an outdated Swedish system to the new Finnish Criminal Code, which had already been drafted. Incarceration was already taken to mean not only physical restraint and enforced labour, but rehabilitation through education, discipline, and industry. To ensure maximally effective criminal rehabilitation, Finnish law transferred responsibility to the prisoners themselves. They would be living proof that all measures implemented in prisons were introduced for their benefit. Therefore, punishment was meted out in direct correlation with prisoners' industriousness and good behaviour. Accordingly, prisoners were divided into 4 classes. Upon reaching the highest class, prisoners had significant economic advantages, their correspondence and visiting rights were increased, as was the choice of activities in their free time. The Finns were already convinced that rehabilitation does not have to begin once an offender is released from prison. And so, as early as 1870, the progressive (for its time) Irish system of criminal rehabilitation was introduced in Finland.

In 1889, the first ever Finnish Criminal Code was put into effect - one of the most innovative among European nations of the time. Its implementation was complicated by conflict with Russian Imperial powers. From 1894, as a result of the new law, restraint was lessened in direct correlation with a prisoner's good behaviour, to the extent of limited release into the community. Moreover, conditional early release, if a prisoner observed certain requirements. In Russia, similar probational release was not introduced until 1909. In the opinion of Finnish society, progressive correctional practices should prepare prisoners for future social reintegration, as well as positively affecting their personal rehabilitation. This emphasis on reintegration found praise in progressive Russian legal literature of the time.

A prison system is formed dependent on a specific country's specific social, economic and political conditions. The Finnish government claimed that towards the end of the $19^{\text {th }}$ century, the better Finnish prisons contained fewer inmates than places $^{9}$. Unfortunately, such a situation turned out to be untenable, because the revolutionary events of 1905-1906 led to an increase in the number of inmates and an overcrowding of prisons.

In this way, the late $19^{\text {th }}$ - early $20^{\text {th }}$ centuries present us with the first successful period in the complex and unstable history of Finnish prison reform.

Amongst scholars, there has long been a one-sided attitude towards this period in Finnish history. Some continue to insist upon the unequivocally negative influ- 
ence of the Russian Empire on the history of the Grand Duchy of Finland. Finnish historians ${ }^{10}$ and criminologists ${ }^{11}$ have published several studies of the Finnish penitentiary system in the Russian Empire but their approach has been too often narrow in concentrating to the dark sides and leaving aside the positive development and reforms of the period. The proper and critical approach to the topic demand that the researcher has disciplinary understanding of history and criminology.

However, the view expressed by many Finnish and Russian researchers and supported by an American researcher, seems to me more objective: "Finland enjoyed substantial autonomy, especially when it came to domestic matters".

"Meanwhile in Finland, Russia had provided its Grand Duchy with substantial legal autonomy. For that reason, Finland maintained the Swedish penal code provisions for most of the $19^{\text {th }}$ century. In 1889, Finland eventually replaced the Swedish penal code provisions of 1734 with its own Finnish Criminal Code. This code, which remained heavily influenced by Swedish legislation, is still in use today but has since been amended and reformed several times" ${ }^{12}$.

The assertions ${ }^{13}$ seems all the more groundless, if one considers that as early as 1814 the first Finnish commission for drafting a new Criminal Code was formed. In the 75 years that followed, commissions of experts were dissolved and re-assembled in response to party politics and internal resistance ${ }^{14}$. In 1889, Russian Imperial power postponed the Code's implementation until 1894. According to Russian experts, the creation of the Code defined Finland as an independent state, and Russia with relation to it as a distinctly foreign authority. The resulting increase in Finnish independence led to inevitable conflict with Russian Imperial interests, as well as to gradual changes in government policy. However, Finland was in many ways the favourite model of Russian progressivist $\operatorname{circles}^{15}$. To many Russians, the reforms implemented by Finland were a western exception to the Empire's rule. Rather, they were an example to be followed.

Moreover, Finland's legal autonomy enabled it to create a centralised prison management system. In 1869, the role of prison inspector was temporarily introduced, followed by the prison management system in 1881 .

Finland was a very special part of the Empire. Though Finland had been a part of Russia since 1809, its criminal and penal policies were Scandinavia-oriented. As national self-awareness grew, and suitable conditions for the development of state structures were created by the metropole, Finnish autonomy was able to successfully develop democratic principles, including the defense of human rights. The Finnish criminal justice system was created under the influence of European science and practice. Prison reform was conducted rationally and vigorously. The stable political situation and improvement of living standards under autonomy only corroborated this. In just three decades, beginning in the 1860s, Finland had gained a prison system which met international standards of the time ${ }^{16}$. By then, rehabilitation of prisoners had already become a key component of Nordic correctional practice. Effective penitentiary legislation and independent prison management in the Grand Duchy 
only expedited transformations. Russian criminal legislation ${ }^{17}$ had practically no effect on the developed legal system of Finland, regardless of the fact that Finland was an integrated part of the Russian Empire.

The historical process that led to today's Finnish penitentiary model was founded on pan-Scandinavian principles of equality and prosperity, including legislative initiative and close collaboration between politicians and experts. Here we see early examples of the respect towards intellectuals and expert knowledge, which began to re-shape the politics of criminal justice in this country as early as the mid-19 ${ }^{\text {th }}$ century ${ }^{18}$.

Today there is common public discussion about excellence of the Scandinavian penitentiary system. That is the system what was established also in Finland only about 150 years ago. The potential for prison reform, which Finland demonstrated in the second half of the $19^{\text {th }}$ century, was so great that it remains relevant to this day.

1 Garland D. Punishment and Modern Society. A Study in Social Theory. Chicago, IL: The University of Chicago Press, 1990; Frameworks of inquiry in the sociology of punishment // British Journal of Sociology. 1990. Vol. 41. N 1. P. 1-15; Sociological perspectives on punishment // Crime and Justice. 1991. N 14. P. 115-165.

2 Scandinavian Penal History, Culture and Prison Practice: Embraced by the Welfare State? / Ed. by P. Scharff Smith, T. Ugelvik. London, United Kingdom: Palgrave MacMillan, Palgrave studies in prisons and penology, 2017.

3 Pratt J. Scandinavian Exceptionalism in an Era of Penal Excess. Part I: The Nature and Roots of Scandinavian Exceptionalism / B British Journal of Criminology. 2008. N 48 (2). P. 119-137.

4 Juntunen A. Ssylka finnov v Sibir' iz avtonomnogo Velikogo Knyazhestva Rossiiskoi imperii i ssyl'nye v Sibiri: Rezyume. Hel'sinki, 1984. P. 1.

5 National Archives of Finland. The collection of the Minister of State Secretary`s Office. Report on Internal Regulations in the Grand Duchy of Finland. 1826-1836. Fb. 36. N 1060. P. 6-7.

6 National Archives of Finland. The collections of the General-Governor `s Office. Notes to His Majesty the Emperor about Finland. 1850-1851 гг. Ca 8. N 630-735. P. 118-119.

7 Juntunen A. Ssylka finnov v Sibir' iz avtonomnogo Velikogo Knyazhestva Rossiiskoi imperii i ssyl'nye v Sibiri. Rezyume. Hel'sinki, 1984; Uchastie finnov v stroitel'stve Sibirskoi zheleznoi dorogi. Petrozavodsk, 1992.

8 Resolution on the execution of imprisonment. Collection of resolutions of the Grand Duchy of Finland. 1865-1866. Helsingfors, 1867. No. 27. P. 11.

9 The report of the Prosecutor of the imperial Finnish Senate on judicial proceedings and the supervision of the application of laws in the province, reported to the Finnish Diet in 1907. Helsingfors, 1911.

10 Virtanen V. Rangaistusjärjestelmän uudistus Suomessa 1800-luvun loppupuoliskolla. Vankeinhoito. Helsinki, 1938; Laitinen J. Vankeinhoidon voimavarojen kehitys 1860-luvulta nykypäivään. Suomen vankeinhoidon historia. Helsinki, 1981. An exception is the study by A. Juntunen (Suomalaisten karkottaminen Siperiaan autonomian aikana ja karkotetut Siperiassa. Turku, 1983), which is widely used Russian-language sources.

11 Vuorela M. The Historical Criminal Statistics of Finland 1842-2015 - a Systematic Comparison to Sweden // International Journal of Comparative and Applied Criminal Justice. 2017. URL: https://www.tandfonline.com/doi/full/10.1080/01924036.2017.1295395; Criminality 
and the Finnish Famine of 1866-1868 // COLLeGIUM: Studies across disciplines in the humanities and social sciences. N 22. P. 119-150.

12 Schartmueller D. Life Imprisonment in Scandinavia. The Ultimate Punishment in the Penal Environments of Denmark, Finland, and Sweden (Flagstaff, Unpublished PhD Thesis, Northern Arizona University). 2015.

13 E. g. "Due to the Russian oppression, Finland was unable to reform the criminal justice system as quickly as Sweden and it was not until 1894 that the Finnish criminal code came to force" (Vuorela M. The historical criminal statistics of Finland 1842-2015 - a systematic comparison to Sweden. Published online: 01 Mar 2017).

14 Dusaev R. N. Ugolovnoe ulozhenie Velikogo Knyazhestva Finlyandskogo. Istoriya sozdaniya, osnovnye instituty. Leningrad, 1988.

15 Klinge M. Imperskaya Finlyandiya. SPb., 2005; Vihavainen T. Stoletiya sosedstva: Razmyshleniya o finsko-russkoi granice. SPb., 2012; Yussila O. Velikoe knyazhestvo Finlyandskoe 18091917. Hel'sinki, 2009; Velikie mify finlyandskoi istorii. Hel'sinki, 2013.

16 Grotenfelt A. Prison condition in the Grand Duchy of Finland. Report submitted by the Finnish Prison Administration in April 1890. Helsingfors, 1890.

17 The Criminal Code of the Russian Empire was adopted in 1903.

18 Lappi-Seppälä T. Trust, welfare, and political culture: explaining differences in national penal policies // Crime and justice: a review of research. Vol. 37 / Ed. M. Tonry. Chicago: The University of Chicago Press, 2008. P. 313-387.

\section{References}

Criminality and the Finnish Famine of 1866-1868 // COLLeGIUM: Studies across disciplines in the humanities and social sciences. N22. P. 119-150.

DUSAEV R.N. Ugolovnoe ulozhenie Velikogo Knyazhestva Finlyandskogo. Istoriya sozdaniya, osnoznye instituty. Leningrad, 1988.

GARLAND D. Punishment and Modern Society. A Study in Social Theory. Chicago, IL: The University of Chicago Press, 1990.

GARLAND D. Frameworks of inquiry in the sociology of punishment // British Journal of Sociology. 1990. Vol. 41. N1. P. 1-15.

GARLAND D. Sociological perspectives on punishment // Crime and Justice. Vol. 14. Chicago, IL: The University of Chicago Press, 1991. P. 115-165.

GROTENFELT A. Tyuremnoye delo $v$ Velikom Knyazhestve Finlyandskom. Otchyot, predstavlenny finlyandskim Tyuremnym Upravleniyem v aprele 1890. Gelsingfors, 1890. 1983.

JUNTUNEN A. Suomalaisten karkottaminen Siperiaan autonomian aikana ja karkotetut Siperiassa. Turku,

JUNTUNEN A. Ssylka finnov v Sibir' iz avtonomnogo Velikogo Knyazhestva Rossiiskoi imperii i ssyl'nye v Sibiri. Rezyume. Hel'sinki, 1989.

JUNTUNEN A. Uchastie finnov v stroitel'stve Sibirskoi zheleznoi dorogi. Petrozavodsk, 1992.

KLINGE M. Imperskaya Finlyandiya. St. Petersburg, 2005.

LAITINEN J. Vankeinhoidon voimavarojen kehitys 1860-luvulta nykypäivään.Suomen vankeinhoidon historia. Helsinki, 1981.

LAPPI-SEPPÄLÄ T. Trust, welfare, and political culture: explaining differences in national penal policies // Crime and justice: a review of research. Vol. 37 (ed. by Michael Tonry). Chicago: The University of Chicago Press, 2008. P. 313-387.

ORFINSKAYA [KANGASPURO] L. V. Kistorii razrabotki i osushchestoleniya finlyandskoy tyuremnoy reformy $v 19$ veke //Vestnik molodykh uchyonykh. Ser. 1. Istoricheskiye nauki. Vyp. 2. St. Petersburg, 2006. S. 53-64.

Otchet prokurora finlyandskogo Senata v $1907 \mathrm{~g}$. Gelsingfors, 1911.

Postanovleniye o ispolnenii nakazany lisheniyem svobody. Sbornik postanovleny Velikago Knyazhestva Finlyandskago. 1865-1866. Gelsingfors, 1867. 
PRATT J. Scandinavian Exceptionalism in an Era of Penal Excess. Part I: The Nature and Roots of Scandinavian Exceptionalism // British Journal of Criminology. 2008. N48 (2). P. 119-137.

Scandinavian Penal History, Culture and Prison Practice: Embraced by the Welfare State? / Ed. by P. Scharff Smith, T. Ugelvik. London, United Kingdom: Palgrave MacMillan, Palgrave studies in prisons and penology, 2017.

SCHARTMUELLER D. Life Imprisonment in Scandinavia. The Ultimate Punishment in the Penal Environments of Denmark, Finland, and Sweden (Flagstaff, Unpublished Ph. D. Thesis, Northern Arizona University). 2015.

VIHAVAINEN T. Stoletiya sosedstva. Razmyshleniya o finsko-russkoi granice. St. Petersburg, 2012.

VIRTANEN V. Rangaistusjärjestelmän uudistus Suomessa 1800-luvun loppupuoliskolla. Vankeinhoito. Helsinki, 1938.

VUORELA M. The Historical Criminal Statistics of Finland 1842-2015 - a Systematic Comparison to Sweden // International Journal of Comparative and Applied Criminal Justice. Published online: 01 Mar 2017. URL: https://www.tandfonline.com/doi/full/10.1080/01924036.2017.1295395.

YUSSILA O. Velikoe knyazhestvo Finlyandskoe 1809-1917. Hel'sinki, 2009.

YUSSILA O. Velikie mify finlyandskoi istorii. Hel'sinki, 2013.

\section{ДЛЯ ЦИТИРОВАНИЯ}

\section{Л. В. Кангаспуро. Великое княжество Финляндское и «другая» тюрьма в Российской империи // Петербургский исторический журнал. 2021. № 1. С. 76-82}

Аннотация: Модернизация тюрем и создание центрального тюремного органа в Финляндии были связаны с общей реорганизацией управления и законодательства в автономии во 2-й половине XIX в. В сообщении рассматривается, как пенитенциарные реформы, проведенные в Великом княжестве Финляндском, были восприняты с имперской точки зрения. Хотя тюремный вопрос хорошо изучен как в России, так и на Западе, целостный подход в транснациональном контексте широко не рассматривался. Сравнение социокультурных различий в восприятии закона и тюремного заключения в империи и в автономии откроет новые перспективы понимания современного контекста проблемы.

Ключевые слова: Великое княжество Финляндское, Российская империя, пенитенциарные реформы, имперская власть, правовое положение автономии.

\section{FOR CITATION}

\section{V. Kangaspuro. The Grand Duchy of Finland and "other" prison in the Russian empire // Petersburg historical journal, no. 1, 2021, pp. 76-82}

Abstract: The modernization of prisons and the establishment of central prison administration in Finland were linked to a general reorganization of the government and the legislation in the autonomy in the second half of the $19^{\text {th }}$ century. This study explores how penitentiary reforms conducted in the Grand Duchy of Finland were perceived from an imperial point of view. Although the prison issue has been well studied both in Russia and in the West, there has been a lack of holistic approach in the transnational context. Comparison of socio-cultural differences in the perception of the law and the imprisonment of the empire and the autonomy will create new perspectives of understanding the contemporary context of the problem.

Key words: the Grand Duchy of Finland, the Russian Empire, penitentiary reforms, imperial power, the legal status of autonomy.

Автор: Кангаспуро, Лариса Викторовна - к. и. н., научный координатор, Александровский институт, университет Хельсинки, Финляндия.

Author: Kangaspuro, Larisa Viktorovna - Ph. D., research coordinator, Aleksanteri Institute, University of Helsinki, Finland.

E-mail: larisa.kangaspuro@helsinki.fi 